\title{
Late-onset persistent retinal microvascular changes after bone marrow transplantation: 3-year follow-up
}

\author{
Alterações microvasculares retinianas de aparecimento tardio e persistente após \\ transplantede medula:seguimentode3anos
}

\author{
Cristina Muccioli ${ }^{1}$ \\ Rubens Belfort $\mathbf{J r}^{2}$ \\ Rodrigo Jorg' $\mathbf{e}^{3}$ \\ Michel Eid Farah ${ }^{4}$ \\ Mauricio B. Pereira ${ }^{5}$
}

\begin{tabular}{|l|}
\hline ABSTRACT \\
\hline Purpose: To describe a case of persistent retinopathy after bone marrow \\
transplantation in the absence of radiation therapy. Methods: Case Report. \\
Results: A 42 year-old man developed bilateral visual loss 15 months after \\
receiving a bone marrow transplant for acute leukemia. The patient was \\
treated with a high dose of cyclosporin A and oral corticosteroids. No \\
radiation therapy was given. Late-onset, multiple, bilateral cotton-wool \\
spots developed 15 months after the bone marrow transplantation and still \\
persist. After three years other cotton-wool spots arose in the absence of \\
any immunosuppressive therapy. Conclusions: Bone marrow transplan- \\
tation microvasculopathy of the retina may be related to certain combina- \\
tions of chemotherapy drugs or immunosuppression itselfand may persist \\
in the absence of these immunosuppressive drugs.
\end{tabular}

Keywords: Bone marrow transplantation; Adrenal cortex hormones/adverse effects Cyclosporins/adverse effects; Retinal diseases; Drug combinations; Case report; Follow-up

The most usual late ocular complications after bone marrow transplantation (BMT) are: retinal microvasculopathy, cataract formation and keratoconjunctivitis sicca syndrome. Ischemic fundus lesions after bone marrow transplantation have been reported since $1983^{(1)}$. Typical lesions are bilateral and localized in the posterior pole and around the optic nerve head ${ }^{(2)}$. They usually appear 3 to 6 months ${ }^{(2-3)}$ after bone marrow transplantation and have a spontaneous complete resolution in some months. Here we report a case of a late-onset and persistent BMT retinopathy with appearance of new cotton-wool exudates after three years of the diagnosis of the disease and presumably related to a previous immunosuppressive therapy.

A 42 year-old HIV-negative man complained of deteriorating vision in both eyes 15 months following bone marrow transplantation (BMT). Cyclosporin A was used as immunosuppressive therapy to treat the graftversus-host disease. The patient was receiving $100 \mathrm{mg}$ prednisone daily. Visual acuity was 20/20 in the RE and 20/25 in the LE. Color vision as well as contrast sensitivity were normal. Biomicroscopic evaluation was unremarkable and no inflammatory cells were seen in the vitreous. Retinal examination disclosed multiple cotton-wool spots and hemorrhages in the nerve fiber layer of both eyes. A Roth spot was present in the retina of the RE (Figure 1). Fluorescein angiography disclosed capillary nonperfusion and leakage from microvascular abnormalities at the edges to the nonperfused areas (Figure 2). During the following two years the patient developed significant posterior subcapsular lens opacities. Phacoemulsification with acrylic IOL implanted was performed in both eyes restoring vision of 20/20 OU. 


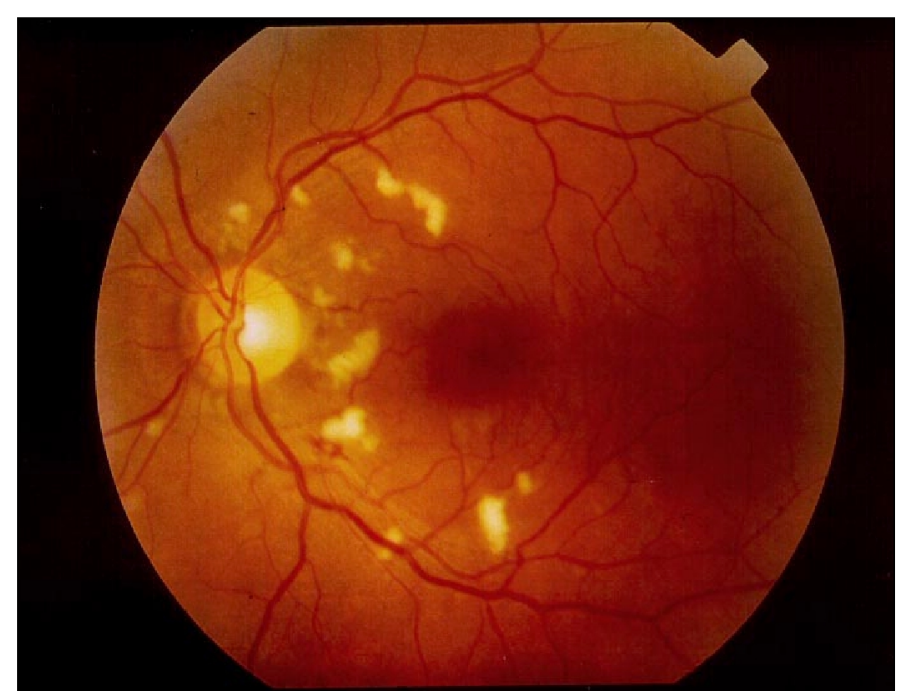

Figure 1 - Color fundus photograph showing multiple cotton-wool spots and a Roth spot close to the inferior temporal arcade

Three years later some of the cotton-wool exudates persisted and two new ones appeared in the perimacular regions without any changes in visual acuity.

The pathogenesis of bone marrow transplantation retinopathy is controversial. Several etiologies such as viral infections, irradiation, graft-versus-host disease and toxicity due to cyclosporin A have been suggested ${ }^{(1-2)}$. Previous reports have documented ischemic fundus lesion in BMT recipients treated with the combination of cyclosporin A and total body irradiation.

The ischemic fundus lesions are a frequent complication after bone marrow transplantation and are more likely to appear in the first 6 months after the transplantation and are usually reversible after the withdrawal of the cyclosporin A. This patient has shown that retinopathy may have a later onset and new cotton-wool exudates appeared years after the withdrawal of the immunosuppressive drugs.

These ocular fundus manifestations might represent a systemic microangiopathy, similar to the one observed in HIVpositive patients. Both situations may have as a cause the profound depression of cellular immunity as the causative mechanism $^{(4)}$.

\section{RESUMO}

Objetivo: Descrever um caso de retinopatia persistente em transplante de medula na ausência de radioterapia prévia. Métodos: Relato de caso. Resultados: Paciente de 42 anos,

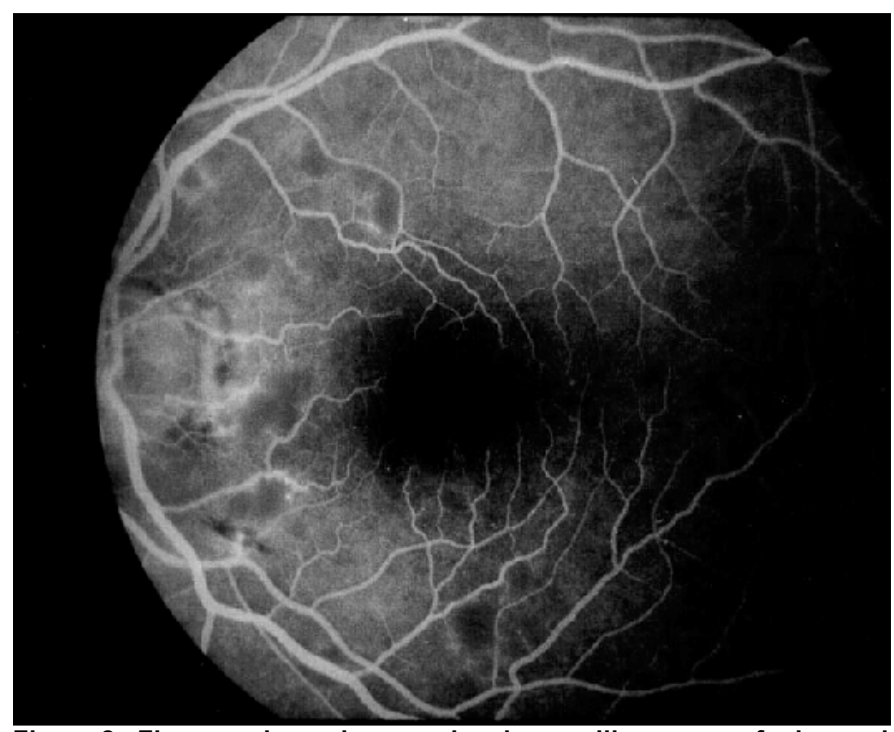

Figure 2 - Fluorescein angiogram showing capillary nonperfusion and leakage from microvascular abnormalities

sexo masculino, que apresentava diminuição bilateral da acuidade visual 15 meses após ser submetido a transplante de medula para tratamento de leucemia aguda. O paciente foi tratado com alta dose de ciclosporina A e corticosteróide oral. Nenhum tratamento adicional de radioterapia foi utilizado. Quinze meses após o transplante de medula o paciente apresentava exsudatos algodonosos múltiplos em ambos os olhos que persistem (3 anos após o transplante). Conclusão: Os exsudatos algodonosos podem ocorrer em pacientes submetidos a tratamento com combinações de quimioterapia ou imunossupressores e podem persistir na ausência de tratamento imunossupressor.

Descritores: Transplante de medula óssea; Corticosteróides/ efeitos adversos; Ciclosporinas/efeitos adversos; Doenças retinianas; Combinação de medicamentos; Relato de caso; Seguimentos

\section{REFERENCES}

1. Gratwohl A, Gloor B, Hahn H, Speck B. Retinal cotton-wool patches in bone-marrow transplant recipients [letter]. N Engl J Med 1983;308:1101.

2. Bernauer W, Gratwohl A, Keller A, Daicker B. Microvasculopathy in the ocular fundus after bone marrow transplantation. [comment on Ann Intern Med 1992;116:956-7]. Ann Intern Med 1991;115:925-30

3. Coskuncan NM, Jabs DA, Dunn JP, Haller JA, Green WR, Vogelsang GB, et al. The eye in bone marrow transplantation. VI Retinal complications. Arch Ophthalmol 1994;112:372-9.

4. Webster AR, Anderson JR, Richards EM, Moore AT. Ischaemic retinopathy occurring in patients receiving bone marrow allografts and campath-1G: a clinicopathological study. Br J Ophthalmol 1995;79:687-91. 